\title{
Ricania japonica (Hemiptera: Ricaniidae)'nın Biyolojik Mücadelesinde Kullanılabilecek Potansiyel Doğal Düşmanların Belirlenmesi
}

\author{
Mustafa TÜFEKLI ${ }^{1}$, Şebnem TİRENG KARUT ${ }^{1 *}$, Vahdettin AKMEŞE ${ }^{1}$, Reyhan \\ SEKBAN $^{2}$, Emine AYDIN ${ }^{2}$, Şemsi KARADENIZ ${ }^{2}$
}

ÖZ

Ricania japonica (Walker, 1851) (Hemiptera: Ricaniidae) Doğu Karadeniz bölgesinde önemli bir zararlıdır. Bölgede çay üretimi yapılmasından dolayı mücadelesinde kimyasallar yerine biyolojik mücadele gibi alternatif mücadele yöntemleri ön plana çıkmaktadır. Bu nedenle ele alınan bu çalı̧̧mayla $R$. japonica'nın biyolojik mücadelesinde kullanılma potansiyeli olan doğal düşmanların belirlenmesi amaçlanmıştır. Çalışma 2017-2020 yılları arasında Doğu Karadeniz Bölgesine bağlı Trabzon, Rize ve Artvin illerinde bulunan zararlı $R$. japonica ve konukçuları üzerinde yürütülmüştür. Çalışmada zararlının doğal biyolojik mücadelesine katkı sağlayacak çok sayıda predatör ve parazitoit tür saptanmıştır. Bu doğal düşmanlardan Aprostocetus sp. ve Polynema sp. zararlıya karşı olası potansiyel parazitoidler olarak belirlenmiştir. Ayrıca ölü $R$. japonica erginlerinden yapılan izolasyonlar sonucunda zararlının entomopatojen fungus Beauveria bassiana tarafından enfekte edildiği saptanmıştır. Bu çalışmada saptanan parazitoit türler ve entomopatojen fungus ile yapılacak ayrıntılı çalışmaların zararlının biyolojik mücadelesine önemli katkılar sunabileceği düşünülmektedir.

Anahtar kelimeler: Ricania japonica, Aprostocetus sp., Polynema sp., Beauveria bassiana, biyolojik mücadele

\section{Determination of Potential Natural Enemies That Can Be Used in Biological Control of Ricania japonica (Hemiptera: Ricaniidae)}

\begin{abstract}
Ricania japonica (Walker, 1851) (Hemiptera: Ricaniida) is an important pest in the Eastern Black Sea Region. Due to the tea production, alternative management methods such as biological control should be used instead of chemical control in the region. Therefore, natural enemies that have potential to use in biological control of $R$. japonica were determined in this study. The study was carried out with pest $R$. japonica and its hosts in Trabzon, Rize and Artvin provinces of the Eastern Black Sea Region between 2017-2020. Many predator and parasitoid species that will contribute to the natural biological control of the pest were determined. Among them, Aprostocetus sp. and Polynema sp. were determined as potential parasitoids against the pest. Additionally, according to isolations made from dead $R$. japonica adults, it was determined that the pest was infected by the entomopathogenic fungus Beauveria bassiana. It is thought that results of the detailed studies which will be made with the parasitoid species and entomopathogenic fungi identified in this study can contribute significantly on biological control of the pest.

Keywords: Ricania japonica, Aprostocetus sp., Polynema sp., Beauveria bassiana, biological control

ORCID ID (Yazar sirasina göre)

0000-0003-1247-2665, 0000-0002-1634-724X，0000-0001-6605-4114，0000-0002-6816-1762, 0000-0001-9032-8525, 0000-0003-0998-642X
\end{abstract}

Yayın Kuruluna Geliş Tarihi: 22.02.2021

Kabul Tarihi: 19.05.2021

${ }^{1}$ Biyolojik Mücadele Araştırma Enstitüsü, Adana

${ }^{2}$ ÇAYKUR Atatürk Çay ve Bahçe Kültürleri Araştırma Enstitüsü, Rize

*E-posta: sebnem.tirengkarut@ tarimorman.gov.tr 


\section{Ricania japonica (Hemiptera: Ricaniidae)'nın Biyolojik Mücadelesinde Kullanılabilecek Potansiyel Doğal Düssmanların Belirlenmesi}

\section{Giriș}

Doğu Karadeniz Bölgesi çay, fındık ve kivi üretimi bakımından Türkiye'nin en önemli bölgesidir. Doğu Karadeniz Bölgesinde 848.801 dekar alanda yaklaşık 1.450 .000 ton yaş çay üretimi yapılmaktadır. Bölgede çay üretiminin yaklaşı1k \%67'si Rize, \%21'i Trabzon, \%10'u ise Artvin illerinde gerçekleşmektedir (TÜİK, 2019). Türkiye'deki findık üretiminin yaklaşık \%20'si, Doğu Karadeniz olarak bilinen GiresunArtvin bölgesinde gerçekleştirilmektedir (TÜIKK, 2019). Kivi üretiminin de en önemli merkezi durumunda olan Karadeniz Bölgesi'nde, 5.921 dekar üretim alanı ve 9.658 tonluk üretim ile Doğu Karadeniz üretimin \%15'ini karşılamaktadır (TÜİK, 2019).

Doğu Karadeniz Bölgesi'nde yetiştirilen kültür bitkilerinde genellikle kimyasal mücadeleyi gerektirecek şekilde hastalık ve zararlı bulunmamaktadır. Çay yetiştiriciliğinde de zararlılar açısından doğal denge mevcut olup herhangi bir kimyasal mücadeleye ihtiyaç duyulmamaktadır. Kivi ve çay yetiştirilen alanlar ile sebze, meyve ve diğer tarla ürünlerinin yetiştiriciliği yapılan alanlar genellikle ev bahçeleriyle iç içe olup herhangi bir kimyasal mücadeleye gerek duyulmadığı, fındık alanlarında ise çoğunlukla ilaçlama yapılmadığ $1 \mathrm{Ak}$ ve ark. (2015) tarafindan da bildirilmektedir.

Türkiye için yeni bir zararlı olan ve ilk tespit edildiğinde Ricania simulans (Walker, 1851) olarak isimlendirilen zararlı daha sonra $R$. japonica (Melichar, 1898) (Hemiptera: Ricaniidae) olarak teşhis edilmiştir (Şekil 1). Zararlının Doğu Karadeniz sahil şeridinde 2006 yılından beri özellikle tarım alanlarında zarara neden olduğu bilinmektedir (Göktürk ve Mihlı, 2015). Gürcistan ile Türkiye arasındaki sınır haraketliliği nedeniyle bulaşık bitki materyalleri ile ülkemize bulaştığı bildirilmiştir (Ak ve ark., 2015). 2006'dan önce Türkiye'de bulunmayan ve anavatanının Çin olduğu bilinen $R$. japonica'nın ülkemizdeki yayılış alanı ve popülasyonu gün geçtikçe artmaktadır (Akıner ve ark., 2020).

1956 y1lında Abhazya'da (Rusya) saptanan, oradan Karadeniz'in subtropik sahilleri boyunca yayılarak Kafkasya'ya ulaşan tür; bögürrtlen, çay, asma, turunçgiller, şeftali ve soya fasulyesi gibi bitkilerde beslenmektedir (Avidzba ve Bobokhidze, 1982). Zararlı, kışı yumurta döneminde geçirmekte ve yılda bir döl vermektedir (Göktürk ve Aksu, 2014). Kivinin önemli bir zararlısı olan ve $R$. japonica ile benzer biyolojik özelliklere sahip Scolypopa australis (Walker, 1851) (Hemiptera: Ricaniidae) kivi bahçelerinde önemli ekonomik kayıplara neden olmakta ve zararlıya karşı geniş spektrumlu ilaçlar kullanılmaktadır (Logan ve ark., 2002; Charles ve Allan, 2004). Göktürk ve Aksu (2014) 2010-2013 yıllarında HopaKemalpaşa'da yürüttükleri çalışmada $R$. japonica'nın da kivi bitkisinin ince sürgünlerde yoğun bir şekilde beslendiğini belirlemişlerdir. Geniș konukçu dizisinin olması, hızla yayılması ve benzer akraba türlerin ekonomik kayılara neden olması gibi nedenlerden dolayı, zararlı başta Karadeniz olmak üzere kivi üretimi yapılan diğer bölgeler için de potansiyel bir risk oluşturmaktadır.

Ak ve ark. (2013), Doğu Karadeniz Bölgesi'nde ki en önemli bitkisel ürünlerden olan çay bitkisinde kimyasal gübre dişında herhangi bir kimyasal kullanılmadığını ve çayda bulunan zararlıların popülasyonunun ekonomik zarar seviyesinin altında, denge halinde olduğunu bildirmişlerdir. Araştırıcılar, tarım arazilerinin genel yapıs1 nedeniyle birçok üründe yetiştiriciliğin çayla iç içe ve karışık bir şekilde yapıldığını, bu nedenle de $R$. japonica' ya karşı kimyasal mücadeleye yönelik tedbirlerin düşünülmediğini belirtmişlerdir. Buna ek olarak Türkiye'de çay üretimi yapılan alanlarda, zararlı organizmalara karşı Bitki Koruma Ürünlerine ruhsat verilmemesi ve ilaçlama yapıldığına dair herhangi bir kayıt bulunmaması, bölgede doğal dengenin korunmas1 nedeniyle kimyasal mücadeleye ihtiyaç duyulmamıştır. Son yıllarda popülasyonu artış gösteren zararlı çay alanlarında üreticiyi tedirgin etmekte ve diğer kültür bitkilerinde ise ileriki yıllarda ekonomik önemde ürün kayıplarına neden olacağ 1 düşünülmektedir. Bölgede mevcut doğal yapının korunması için zararlıya karşı kimyasal mücadeleye alternatif kültürel, biyoteknik ve biyolojik mücadele gibi diğer mücadele yöntemlerinin belirlenmesi gerekmektedir. Bu yöntemler içerisinde parazit, predatör ve 


\section{Ricania japonica (Hemiptera: Ricaniidae)'nın Biyolojik Mücadelesinde Kullanılabilecek Potansiyel Doğal Düşmanların Belirlenmesi}

entomopatojenlerin kullanıldığı biyolojik mücadele ön plana çıkmaktadır. Bu sebeple ele alınan bu çalışmada $R$. japonica'nin biyolojik

mücadelesinde kullanılma potansiyeli olan doğal düşmanların belirlenmesi amaçlanmıştır.

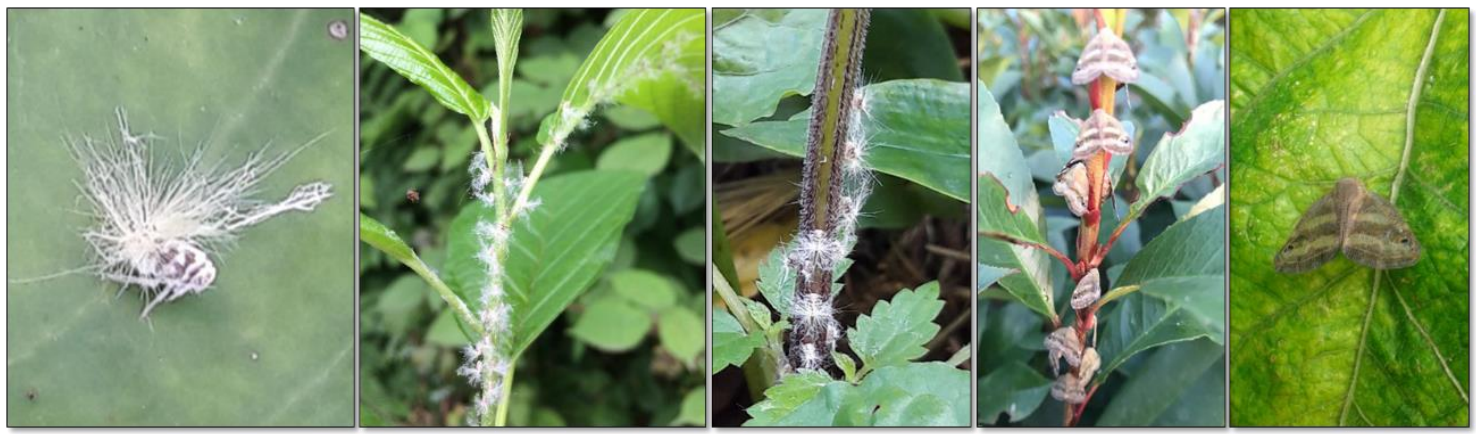

Şekil 1. Ricania japonica'nın nimf ve ergin bireylerinin görünümü

\section{Materyal ve Yöntem \\ Doğal Düşmanların Belirlenmesi}

Ricania japonica'nın parazitoit ve predatörlerini belirlemek için Doğu Karadeniz Bölgesi'nde (Trabzon, Rize, Artvin) 2017, 2018 ve 2019 yıllarında Mart ayından Kasım ayı sonuna kadar 15 günlük periyotlarla arazi çıkışları yapılmıştır. Arazi çalışmalarında her ili temsil edecek şekilde, konukçu bitkilerden toplam alanın, $\% 0.01$ 'i esas alınarak örnekleme yapılmıştır (Bora ve Karaca, 1970).

\section{Predatörlerin Belirlenmesi}

Ricania japonica'nin avcılarını belirlemek için örnekleme yapılacak tarla veya bahçeyi temsil edecek şekilde en az beş farklı noktada aynı sıra üzerindeki bitkiler 2-3 dakika gözle kontrol yöntemi ile incelenmiştir. Predatörlerin ergin dönemi ağız aspiratörü ile toplanmış ergin öncesi dönemler ise üzerinde bulunduğu bitki parçası ile beraber veya samur firça yardımıyla alınarak küçük plastik kap, tüp ve polietilen torbalara konularak buz kapları içerisinde laboratuvara getirilmiştir. Laboratuvara getirilen ergin öncesi dönemler zararlının nimflerinin bulunduğu kültür kaplarına aktarılmış ve buradan elde edilen ergin predatörler ağız aspiratörü veya yumuşak pens yardımıyla alınarak öldürme şişesine alınmıştır. Daha sonra iğnelenip etiketlenerek böcek kutuları içerisine yerleştirilmiş ve teşhise hazır hale getirilerek ilgili konu uzmanına gönderilmiştir.

\section{Parazitoitlerin Belirlenmesi}

Ricania japonica'nin yumurta, nimf ve ergin parazitoitlerini belirlemek için bahçeyi temsil edecek şekilde farklı beş noktadan örneklenen bulaşık bitkilerdeki sürgünler kesilerek polietilen torbalara konulmuş ve buz kaplarında laboratuvara getirilmiștir. Laboratuvara getirilen örnekler, bir ucuna cam tüp takılan, 5-10 lt şeffaf kültür kavanozları veya kâğıt torbalar içerisinde parazitoit çıkışı için kültüre alınmıştır. Elde edilen parazitoitler teşhise hazır hale getirilerek ilgili konu uzmanına gönderilmiştir.

\section{Hastalıklı bireylerin toplanması, fungusların izolasyonu ve tanılanması}

Ricania japonica'nın yoğun olarak bulunduğu Rize ilinin merkez, Çayeli, Derepazarı, Pazar ve İyidere ilçelerinden, ölü $R$. japonica erginleri toplanmıştır. Araziden toplanan ölü bireyler böcek toplama kutularına yerleştirilerek Biyolojik Mücadele Araştırma Enstitüsü Dr. Hatice Satar Entomopatojen Laboratuvarı'na getirilmiştir. Laboratuvara getirilen örneklerin $\% 1$ 'lik sodyum hypoclorid solüsyonu içerisinde 3 dakika bekletilerek yüzey sterilizasyonu yapıldıktan sonra üç defa steril saf su ile yıkanmıştır. Daha sonra örnekler içerisinde ıslak kurutma kâğıdı bulunan petrilerde nem çemberine alınmış ve inkübasyona bırakılmıştır. Nem çemberinde mukozlanma görülen örneklerden Potato dextrose agar (PDA) ve Saboraud dextrose agar (SDA) besi yerleri kullanılarak fungus izolasyonu için öze 


\section{Ricania japonica (Hemiptera: Ricaniidae)'nın Biyolojik Mücadelesinde Kullanılabilecek Potansiyel Doğal Düşmanların Belirlenmesi}

yardımıyla inokülasyonu gerçekleștirilmiș ve petriler $28^{\circ} \mathrm{C}$ sicaklıkta muhafaza edilmiștir (Demirbağ ve ark., 2008). İzolasyon sonucunda petride gelişen funguslar incelenmiş ve farklı koloni morfolojisine sahip olanlar saflaştırılmış ve alt kültüre alınmıştır.

Elde edilen fungus izolatlarının moleküler yöntemler kullanılarak tanısını yapmak amacıyla Thermo Scientific (GeneJet genomik DNA Purification Kit) kiti kullanılarak DNA izolasyonu gerçekleştirilmiştir. Ardından elde edilen DNA, ITS1 ve ITS4 bölgelerine ait primer çiftleri kullanılarak PCR (polymerase chain reaction) yöntemi ile çoğaltılmıştır (White ve ark., 1990). PCR reaksiyonu sonucunda elde edilen ürünler \%1.5'luk agaroz jelde görüntülenmiş, pozitif bant elde edilen PCR ürünleri Macrogen firmasına gönderilmiştir. Firma tarafindan pürifikasyona tabii tutularak belirlenen DNA dizileri Bioedit programı kullanılarak düzenlenmiștir. Elde edilen diziler National Center for Biotechnology Information'ın (NCBI) sayfasindan BLAST analizi ile doğrulanmış ve moleküler tanısı yapilan entomopatojen fungusun NCBI'a kaydı yapılmıştır.

\section{Bulgular ve Tartışma \\ Belirlenen Predatör ve Parazitoitler}

Çalışmanın yürütüldüğü 2017-2019 yılları arasında nimf çıkışları başladıktan sonra Haziran ayından zararlının yumurta bırakma döneminin sonuna kadar 15 günlük aralıklarla yapılan arazi çıkışları sonucunda, zararlının nimf dönemi için 156, yumurta dönemi için toplam 351 farklı alandan, yabanciotlar, süs bitkileri ve kültür bitkilerinin üzerinden örnek alınmıştır.

Çalışmada tanısı Prof. Dr. Nedim Uygun tarafından yapılan ve Çizelge 1 ve Şekil 3'te verilen Coleoptera takımı Coccinellidae familyasına ait 6 adet predatör tür belirlenmiştir.

Çizelge 1.2017-2019 yılları arasında yapılan çalışmada tespit edilen ve teşhisi yapılan predatör türler

\begin{tabular}{l|l|l}
\hline Takım & Familya & Tür \\
\hline Coleoptera & Coccinellidae & Brumus (Exochomus) quadripustulatus (Linnaeus, 1758) \\
\hline & & Chilocorus renipustulatus (Scriba, 1791) \\
\hline & & Harmonia axyridis (Pallas) \\
\hline & & Propylea quatuordecimpunctata (Linnaeus, 1758) \\
\hline & & Psyllobora bisoctonotata (Muls.) \\
\hline
\end{tabular}

Coccinellidler genel predatör olup, yaprakbitleri, kabuklubitler, unlubitler, kırmızı örümcekler vb. birçok zararlı ile beslenmektedirler. Zararlı popülasyonlarını ekonomik zarar eşiğinin altında tutmak ve entegre mücadele programlarının geliștirilmesi gün geçtikçe önem kazanmakla birlikte Coccinellidler, entegre zararlı yönetiminde, doğal dengenin korunmasında ve zararlılarla mücadele etmeni olarak doğada yer alması nedeniyle biyolojik mücadele de oldukça önemli bir yere sahiptir (Kılınçer ve ark., 2010; Tunaz ve ark., 2010). Çalışmadan elde edilen Coccinellidae türlerinin $R$. japonica'nın predatörü olduğuna dair bir kaynağa rastlanmamıs olmasiyla beraber bu türlerin zararlının ilk dönem nimfleri ile beslendikleri gözlenmiştir. 


\section{Ricania japonica (Hemiptera: Ricaniidae)'nın Biyolojik Mücadelesinde Kullanılabilecek Potansiyel Doğal Düşmanların Belirlenmesi}
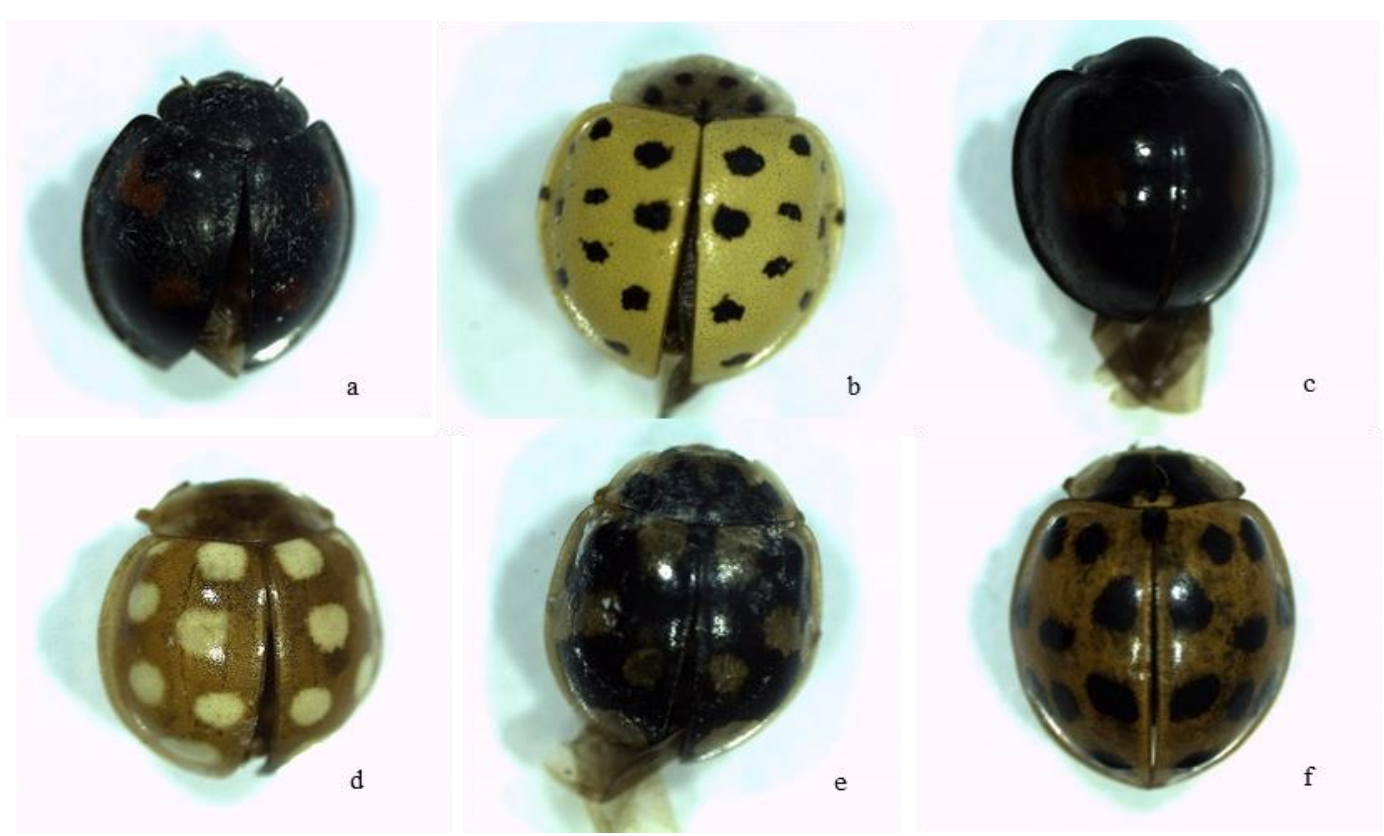

Şekil 3. Çalışmada saptanan Coleoptera takımı Coccinellidae familyasına ait predatör türler: a) Brumus (Exochomus) quadripustulatus, b) Psyllobora bisoctonotata, c) Chilocorus renipustulatus, d) Vibidia duodecimguttata, e) Propylea quatuordecimpunctata, f) Harmonia axyridis

Ülkemizde oldukça önemli türleri bulunan Coccinellidae familyası biyolojik mücadele açısından çok önemlidir. Portakaldalı ve Satar (2010), Propylaea quatuordecimpunctata (L.), ve Chilocorus renipustulatus (Scriba)'nin yaprakbiti, kabuklu bitler, beyazsinek ve külleme mantarı ile beslendiklerini bildirmişlerdir. $\mathrm{Bu}$ çalışmada Rize ilinin Merkez, İyidere ve Derepazarı ilçelerinde turunçgil ağaçları üzerinden toplanan $C$. renipustulatus Uygun (1981) tarafindan Doğu Karadeniz Bölgesi turunçgil alanlarında yapılan bir çalışmada da belirlenmiş ve predatörün yaprakbitleri ve kabuklubitler ile beslendiği belirtilmiștir. Bu çalışmada saptanan Harmonia axyridis 'in Tekirdağ ve Çanakkale illerinde de bulunduğu ve \%10.2 ile toplam türler arasında 5 . sırada olduğu Baştuğ ve Kasap (2015) tarafından bildirilmiştir. Yapılan çalışmalarda Harmonia axyridis' in oldukça hızlı yayılabilen istilacı bir tür olması nedeni ile biyolojik mücadele etmeni olarak sağladığı yararın yanında hedef dışı eklembacaklılar üzerindeki etkilerinin de dikkate alınması gerektiği vurgulanmaktadır (Brown ve ark., 2008; Koch ve Galvan, 2008).

Çalışmada Hymenoptera takımı, Apocrita alttakımına ait 7 familyaya bağlı 12 adet parazitoit tür belirlenmiștir. $\mathrm{Bu}$ türlerden Diadegma semiclausum (Hellen, 1949)'un tanıs1 Prof. Dr. Saliha Çoruh tarafından yapılmıştır. Diğer türlerin tanısı ise bir tür (Tetrastichus agrilocidus Graham, 1991) dışında cins düzeyinde Prof. Dr. Miktat Doğanlar tarafından yapılmış ve listesi Çizelge 2'de verilmiştir. 


\section{Ricania japonica (Hemiptera: Ricaniidae)'nın Biyolojik Mücadelesinde Kullanılabilecek Potansiyel Doğal Düşmanların Belirlenmesi}

Çizelge 2. 2017-2019 yılları arasında yapılan çalışmada tespit edilen ve teşhisi yaptııılan parazitoid türler

\begin{tabular}{l|l|l}
\hline Takım & Familya & Tür \\
\hline Hymenoptera & Encyrtidae & Cheiloneurus $\mathrm{sp}$. \\
\hline & Eulophidae & Aprostocetus $\mathrm{sp}$. \\
\hline & & Chrysocharis $\mathrm{sp}$. \\
\hline & & Entedon $\mathrm{sp}$. \\
\hline & & Pediobius $\mathrm{sp}$. \\
\hline & & Sympiesis $\mathrm{sp}$. \\
\hline & Ichneumonidae & Detrastichus agrilocidus Graham, 1991 \\
\hline & Eupelmidae & Eupelmus $\mathrm{sp}$. \\
\hline & Eurytomidae & Eurytoma $\mathrm{sp}$. \\
\hline & Mymaridae & Polynema $\mathrm{sp}$. \\
\hline & Pteromalidae 1949$)$ \\
\hline & Torymidae & Pteromalus $\mathrm{sp}$. \\
\hline
\end{tabular}

Çalışmada belirlenmiş olan parazitoidlerden Cheiloneurus sp. bir Encyrtidae üyesi olup bazı türleri Coleoptera (Chrysomelidae) ve Hemiptera (Coccidae, Pseudococcidae, Lophopidae) takımından bazı arthropodların parazitoitidirler. Hiperparazitoit olan türleri de mevcuttur (Dobhal, 2014). Chalcidoidea içinde yer alan Encyrtidae üyeleri çeşitli mikrohymenopterlerin en büyük familyalarından biri olup endoparazitoit veya hiperparazitoittirler. Özellikle Hemiptera (çoğunlukla Aphidoidea, Coccoidea ve Psylloidea), Lepidoptera, Neuroptera takımlarına ait bazı arthropodlar ile keneler ve örümceklerin yumurta, larva ve erginlerinin parazitoiti olduğu için ekonomik olarak önemlidirler. Coccidlerin biyolojik mücadelesinde dünya çapında başarıla kullanıldıkları bildirilmiştir (Dobhal, 2014).

$\mathrm{Bu}$ çalışma kapsamında Rize ilinde findık alanlarından alınan örneklerden Eulophidae familyasindan Aprostocetus sp. ve asma bitkisinden alınan örneklerden ise Mymaridae familyasından Polynema sp. tespit edilmiştir (Çizelge 2, Şekil 4). Eulophidae familyasının çok azı bitkiyle beslenmektedir. Buna karşılık çoğu Coleoptera, Diptera, Hemiptera, Hymenoptera ve Lepidoptera takımlarından pek çok eklem bacaklıda iç veya dıș parazittirler (Yefremova ve ark., 2010). Benzer şekilde Mymaridae familyasındaki parazitoit arıcıklar da pek çok böceğin yumurta parazitoitidirler ve biyolojik mücadele etmeni olarak başarıyla kullanılmaktadirlar (Anonymous, 2020b). Ayrıca İtalya'da yapılan bir çalışmada $R$. japonica'ya akraba bir başka tür olan $R$. spekulum (Walker, 1851) (Hemiptera: Ricaniidae)'un yumurtalarından Aprostocetus (Ootetrastichus) crino (Hymenoptera: Eulophidae) ve Polynema sp. tespit edilmiştir (Laudonia ve ark., 2017). Bunun dişında Tayland'da yapılan bir başka çalıșmada, Aprostocetus sp.'nin, çeltikte zararlı Nilaparvata lugens (Stal, 1954) (Hemiptera: Delphacidae)'in de yumurta parazitoiti olduğu bildirilmiştir (Vilaivan ve ark., 2016). Bolu ve Uygun (2003), Türkiye'de 1996-1998 y1lları arasında, Antepfistı̆̆1 bahçelerinde dört Coccoidea türünün yaygınlığı ve doğal düşmanlarının belirlenmesi ile ilgili yapılan çalışmada Polynema sp. (Mymaridae)'nin Coccoidea türlerinin parazitoiti olduğunu belirlemişlerdir. 


\section{Ricania japonica (Hemiptera: Ricaniidae)'nın Biyolojik Mücadelesinde Kullanılabilecek Potansiyel Doğal Düşmanların Belirlenmesi}
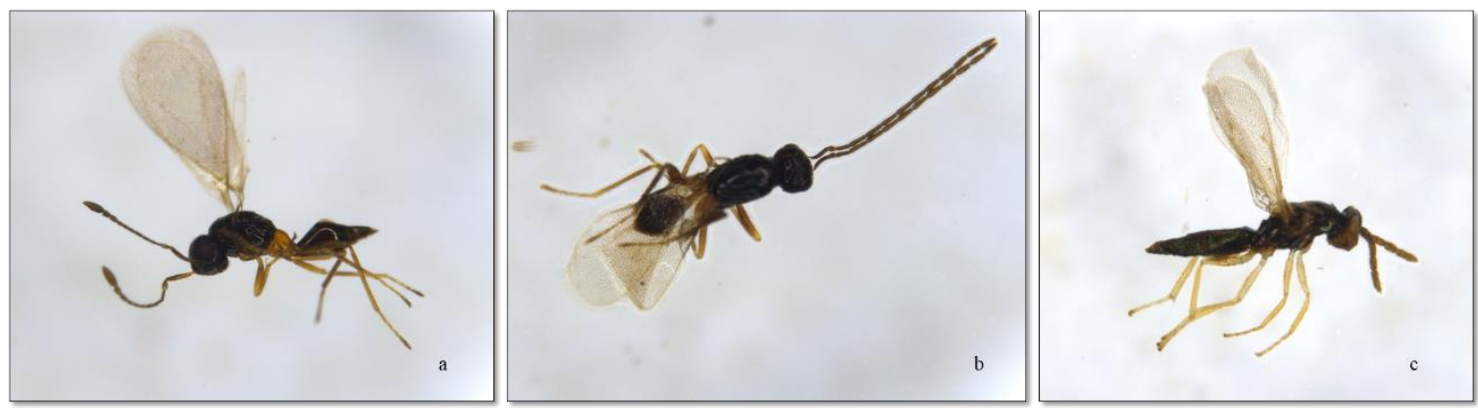

Şekil 4. Bu çalışmada saptanan Polynema sp. (Mymaridae) dişi (a) ve erkek bireyleri (b) ile Aprostocetus sp. (Eulophidae) ergin (c) bireyine ait görüntüler

Her ne kadar toplanarak tanısı yapılmamıș olsa da sörvey çalıșmaları sırasında tarım alanı ve tarım dışı alanlar dahil olmak üzere pek çok yerde genel avc1lar olarak bilinen örümcek (Arachnida) türleriyle karșılașılmıș ve örümceklerin özellikle çay plantasyonlarında bitki üzerini kaplayacak șekilde ağ ördüğü belirlenmiştir (Şekil 2). Bu ağlara takılan zararlının ergin ve nimflerinin bu örümcekler tarafindan avlanıldığı ve zararlının yoğunluğunun azaltılmasında etkili olduğu gözlenmiştir. Sancak (2007) yaptığı çalışmada Doğu Karadeniz Bölgesi'ndeki örümcek (Araneae) türlerini belirlemiş ve en yaygın rastlanan türlerin Agelena labyrinthica (Clerck, 1757) (Agelenidae), Neoscona adianta (Walckenaer, 1802) (Araneidae), Philaeus chrysops (Poda, 1761) (Salticidae), Pardosa hortensis (Thorell, 1872) (Lycosidae), Pholcus phalangioides (Fuesslin, 1775) (Pholcidae) ve Parasteatoda tepidariorum (C. L. Koch, 1841) (Theridiidae) olduğunu belirtmiştir. Çalışmamıza benzer şekilde Cahenzli ve ark. (2017)'nın elma bahçelerinde yaprak bitleri ile ilgili yaptıkları bir çalışmada ilkbaharda örümcek ağ alanlarındaki artıșın yaprakbiti miktarını ve dolayısıyla meyve zararını azalttığını belirlemişlerdir. Karnivor arthropod olan örümcekler dünyanın pek çok ekosistemine adapte olmuşlardır. Son yıllarda yapılan ekolojik ve faunistik araştırmalar örümceklerin en yaygın predatörler olduğunu, biyolojik mücadelede kullanılabileceğini, bu nedenle de örümceklerin biyolojik mücadelede kullanımı veya beslenme ekolojileri üzerine araștırmaların giderek yoğunlaştığını bildirmektedir (Rajeswaran ve ark., 2005; Sancak, 2007).

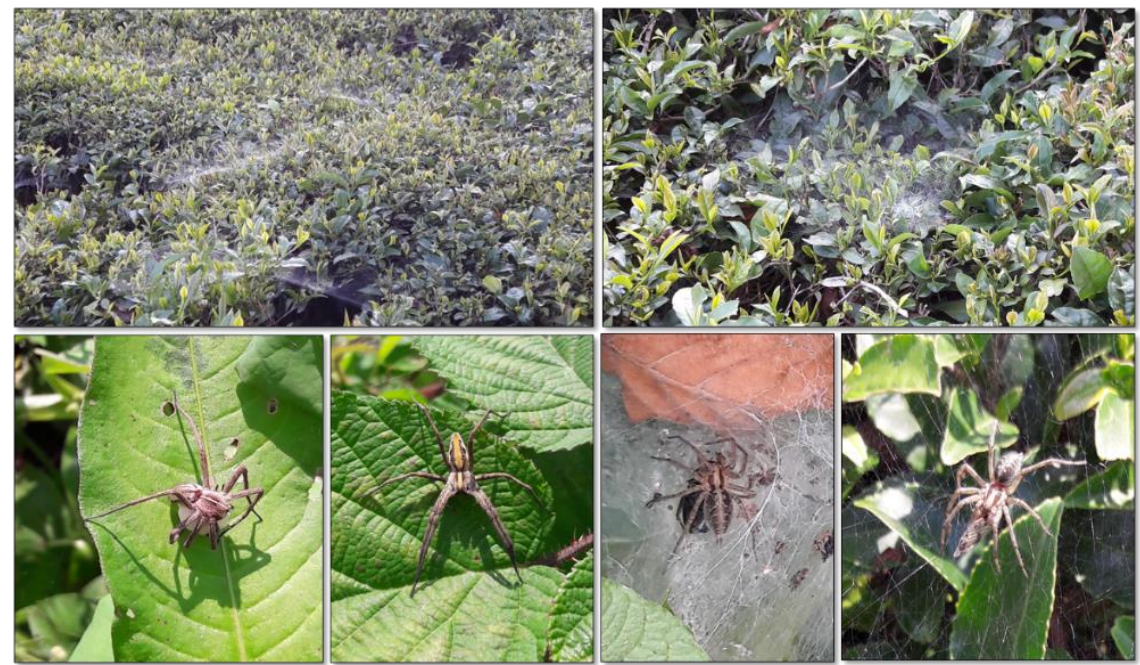

Şekil 2. Çay plantasyonlarında gözlenen, örümceklerin ördüğü ağlar (üstte) ile değişik örümcek türlerinden (altta) görüntüler 


\section{Ricania japonica (Hemiptera: Ricaniidae)'nın Biyolojik Mücadelesinde Kullanılabilecek Potansiyel Doğal Düşmanların Belirlenmesi}

Örümcekler dıșında Türkçede Altın gözlü avcı böcek olarak tanımlanan Chrysoperla spp. (Stephens, 1836) (Neuroptera: Chrysopidae) en çok karşılaşılan diğer bir doğal düşman grubu olmuştur. Genel avc1 olan bu türlerin erginleri nektar, polen ve yaprakbitinin fumajini ile beslenirken, larvaları pek çok zararlıya karşı biyolojik mücadelede kullanılmakta ve dünyanın pek çok bölgesinde yaygın alarak görülmektedir (Anonymus, 2020a).

\section{Toplanan hastalıklı bireylerde belirlenen entomopatojen funguslar}

Yapılan çalışmada, 2019 yılında 7 farklı noktadan 95 adet ölü ergin $R$. japonica örnekleri toplanmıstır (Sekil 5c). Nem çemberine alınan kadavralarda mukozlanma görülen bireylerden yapılan izolasyon sonucunda bireylerin tek bir fungus tarafindan enfekte olduğu belirlenmiştir. Fungus izolatları ölü böcekler üzerinde gelişen enfeksiyon şekli (Şekil 5e) ve değișik besi ortamlarındaki koloni morfolojilerine göre incelenmiştir. Fungus PDA ve SDA besiyerlerinde beyaz miseliyal bir gelişme göstermiş (Şekil 5a), yapılan mikroskobik inceleme sonucunda da küresel, elipsoid yapılar gözlenmiştir. Morfolojik ve mikroskobik inceleme sonucu yapılan tanılama sonuçları moleküler karakterizasyon ile de doğrulanmıştır. Etmen genel bir entomopatojen fungus olan ve pek çok böcek grubunu hastalandırıp ölmesine neden olan Beauveria bassiana (Şekil 5) olarak belirlenmiş, NCBI'a MN822135 numara ve Beauveria bassiana Ric1 ad1 ile kayd1 yapılmıştır.

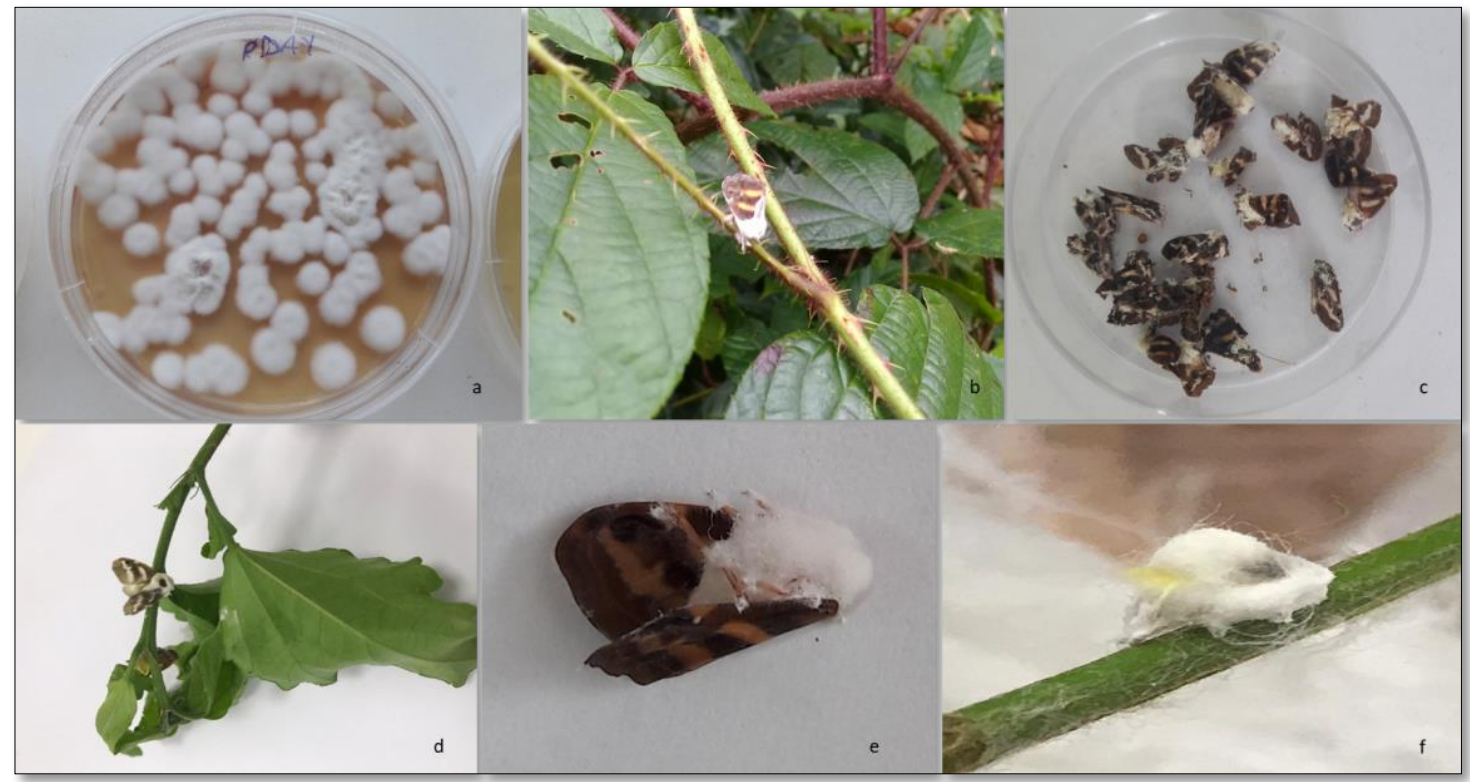

Şekil 5. Bu çalıșmada saptanan Beauveria bassiana'nın; PDA ortamındaki gelișimi (a), ölü ergin Ricania japonica ergin bireyleri (b,c,d,e) ile nimfi (f) üzerindeki görünümü

Beauveria bassiana dünyanın birçok yerinde hem 1lıman hem de tropikal bölgelerde görülebilen, birçok böcek üzerinde yaygın olarak çalışılmış, geniş konukçu dağılımına sahip entomopatojen funguslardan biridir. Hemiptera, Coleoptera, Lepidoptera, Hymenoptera, Diptera ve Acarina vb. içinde olduğu çok geniş bir konukçu dağılımına sahiptir (Zimmermann, 2007). Entomopatojen fungus mikoinsektisit olarak Türkiye'de de trips ve beyazsinek gibi bazı zararlılara karşı kullanılmaktadır (BKÜ, 2020).

\section{Sonuc}

Doğu Karadeniz Bölgesi'nde 2006'dan itibaren Gürcistan'dan bulașik bitki materyalleri ile ülkemize girdiği bildirilen $R$. japonica pek çok kültür bitkisi, yabancı otlar ve süs bitkisinde sorun oluşturmaktadır. Bölgede çay üretimi 


\section{Ricania japonica (Hemiptera: Ricaniidae)'nın Biyolojik Mücadelesinde Kullanılabilecek Potansiyel Doğal Düşmanların Belirlenmesi}

yapilmasindan dolayı mücadelesinde kimyasallar yerine alternatif mücadele yöntemleri ön plana çıkmaktadır. Özellikle biyolojik mücadele içerisinde yer alan parazitoid, predatör ve entomopatojenlerin kullanımı ile beraber yeni stratejiler oluşturulması bölge için önem arz etmektedir. Çalışmada zararlının doğal biyolojik mücadelesine katkı sağlayacak başta Arachnida türleri olmak üzere çok sayıda predatör tür saptanmıştır. Bu türlerin korunup desteklenmesi gerekmektedir. Saptanan doğal düşmanlardan Aprostocetus sp. ve Polynema sp. zararliya karș1 olas1 potansiyel parazitoidler olarak belirlenmiştir. $\mathrm{Bu}$ türlerin etkinliğinin laboratuvar ve arazi çalıșmaları ile ortaya çıkarılması doğal düșmanın kitle halinde üretilip salınması şeklindeki biyolojik mücadele programının uygulanabilmesinin ilk adımı olacaktır. Ayrıca çalışma kapsamında ölü $R$. japonica erginlerinden yapilan izolasyonlar sonucunda zararlının entomopatojen fungus tarafindan enfekte edildiği saptanmış ve etmen B. bassiana olarak belirlenmiştir. Genel bir entomopatojen fungus olan $B$. bassiana'nın çevre dostu mücadele yöntemlerinin uygulanması ile etkinliği yayılacak ve doğada zararlının poplasyonunun baskı altına alınmasında önemli katkılar sunacaktır. Bu çalışma sonucunda yukarıda belirtilen parazitoit türlere ek olarak ümitvar bir entomopatojen fungus ortaya çıarılmış olup, belirtilen doğal düşmanlar ile ilgili daha ayrıntılı çalışmaların yürütülmesi gerekmektedir.

\section{Teşekkür}

Coleoptera takımı Coccinellidae familyasına ait predatörlerin teșhisini yapan Prof. Dr. Nedim Uygun'a, Hymenoptera takımına ait parazitoit türlerin teşhisini yapan Prof. Dr. Miktat Doğanlar ve Prof. Dr. Saliha Çoruh'a, ayrıca çalışmayı destekleyen Tarımsal Araştırmalar ve Politikalar Genel Müdürlüğü'ne (TAGEMBSAD-G-17-A2-P5-770) teşekkür ederiz.

\section{Kaynaklar}

Akıner M. M., Öztürk M., Güney İ. and Usta A. (2020). Natural infection potential and efficacy of the entomopathogenic fungus Beauveria bassiana against Orosanga japonica (Melichar). Egyptian Journal of Biological Pest Control, 30:68.

Ak K., Güçlü S. ve Sekban R. (2013). Doğu Karadeniz Bölgesinde Yeni Bir Zararlı Ricania simulans (Walker, 1851) (Hemiptera: Ricaniidae)'a Karş1 Azadirachtin ve Spinosad Etki Maddeli Biyopestisitlerin Etkinliklerinin Belirlenmesi. Tarım Bilimleri Araştırma Dergisi, 6(1): 10-14.

Ak K., Güçlü Ş., Eken C. ve Sekban R. (2015). Türkiye için yeni bir zararlı Ricania simulans (Walker, 1851) (Hemiptera: Ricaniidae). Türkiye Entomoloji Dergisi, 39(2): 179-186.

Anonymous

https://wellcomecollection.org/works/eka yc6ga, (erişim tarihi 04.11.2020).

Anonymous (2020b). https://en.wikipedia.org/wiki/Chrysoperla _carnea, (erişim tarihi: 04.11.2020).

Avidzba N.S. ve Bobokhidze Z. M. (1982). Biophenology of the Japanese leafhopper. Zashchita Rastenii, No:6, 36pp.

Baştuğ G. ve Kasap İ. (2015). Çanakkale ili Coccinellidae (Coleoptera) familyası üzerine faunistik çalışmalar. Türkiye Biyolojik Mücadele Dergisi, 6(1): 41-50.

BKÜ (2020). Bitki Koruma Ürünleri Veri Tabanı Program. https://bku.tarimorman.gov.tr/Arama/Ind ex, erişim tarihi: 11.11.2020.

Bolu H. ve Uygun N. (2003). Güneydoğu Anadolu Bölgesi antepfistıklarında Coccoidea türleri, yayılış alanları, bulaşma oranları ve doğal düşmanlarının belirlenmesi. Bitki Koruma Bülteni, 43 (14) : 111-123.

Bora T. ve Karaca İ. (1970). Kültür Bitkilerinde Hastalığın ve Zararın Ölçülmesi. Ege Üniv. Matbaası, Bornova/İzmir.

Brown P. M. J., Adriaens T., Bathon H., Cuppen J., Goldarazena A., Hagg T., Kenis M., Klausnitzer B. E. M., Kovar I., Loomans A. J. M., Majerus M. E. N., Nedved O., Pedersen J., Rabitsch W., Roy H. E., Ternois V., Zakharov I. A. and Roy D. B. (2008). Harmonia axyridis in Europe: spread and distribution of a non-native coccinellid. In: From Biological Control 


\section{Ricania japonica (Hemiptera: Ricaniidae)'nın Biyolojik Mücadelesinde Kullanılabilecek Potansiyel Doğal Düşmanların Belirlenmesi}

to Invasion: the Ladybird Harmonia axyridis as a Model Species. H.E. Roy, E. Wajnberg (eds.), pp.:5-21, Springer, doi: 10.1007/978-1-4020-6939-0_2.

Cahenzli F., Pfiffner L. and Daniel C. (2017). Reduced crop damage by self-regulation of aphids in an ecologically enriched, insecticide-free apple orchard. Agronomy for Sustainable Development, 37: 65.

Charles J. G. ve Allan D. J. (2004). Passionvine hopper, Scolypopa australis (Walker) (Hemiptera: Ricaniidae), egg parasitism by Aphelinidae (Hymenoptera) in New Zealand. New Zealand Entomologist, 27: 83-89.

Demirbağ Z., Nalçacioğlu R., Kati H., Demir İ., Sezen K. ve Ertürk Ö. (2008). Entomopatojenler ve Biyolojik Mücadele. Esen Ofset Matbaac1l1k, Trabzon, 325s.

Dobhal, R. (2014). Studies on Biodiversity and Taxonomy of the Family Encyrtidae (Hymenoptera: Chalcidoidea) of Doon Valley. Forest Research Institute University, Department of Forest Entomology, PhD Thesis, Dehradun, Uttarakhand, India, 379 p.

Göktürk, T. ve Aksu Y. (2014). Tarım ve orman alanlarında zarar yapan Ricania simulans (Walker) $1851 \quad$ (Hemiptera: Ricaniidae)'un morfolojisi, biyolojisi ve zarar1. Türkiye II. Orman Entomolojisi ve Patolojisi Sempozyumu Bildiriler Kitab1, 7-9 Nisan 2014, Antalya, Ed: Prof. Dr. Azize Toper Kaygin, s: 279-281.

Göktürk T. ve Mihlı A. (2015). Doğu Karadeniz sahil şeridinin önemli zararlısı Ricania simulans (Walker,1851) (Hemiptera: Ricaniidae)'ın mücadelesi üzerine araştırmalar. Artvin Çoruh Üniversitesi, Orman Fakültesi Dergisi, 16(1): 89-93.

Kilınçer N., Yiğit A., Kazak C., Er M. K., Kurtuluş A. ve Uygun N. (2010). Teoriden pratiğe zararlilarla biyolojik mücadele. Türkiye Biyolojik Mücadele Dergisi, 1(1):15-60.

Koch R. L. and Galvan T. L. (2008). Bad side of a good beetle: the North American experience with Harmonia axyridis. BioControl, 53:23-35.
Laudonia S., Lucchi A., Rossi E. and Viggiani G. (2017). First report on egg-parasitoids of the Asian planthopper Ricania speculum. Bulletin of Insectology, 70(2): 177-180.

Logan D. P., Allison P. A. and Stannard K. (2002). Selection of wild hosts for feeding by Passion vine hopper, Scolypopa australis (Walker) (Hemiptera: Ricaniidae) in the Bay of plenty. New Zealand Plant Protection, 55: 368-373.

Portakaldalı M. ve Satar S. (2010). Artvin ve Rize illeri Coccinellidae (Coleoptera) faunası üzerinde çalışmalar. Bitki Koruma Bülteni, 50(3): 89-99.

Rajeswaran J., Duraimurugan P. and Shanmugam P.S. (2005). Role of spiders in agriculture and horticulture ecosystem. Journal of Food, Agriculture \&Environment, 3(3\&4): 147-152.

Sancak Z. (2007). Doğu Karadeniz Bölgesi Örümceklerinin (Araneae) Sistematik ve Faunistik Açıdan İncelenmesi. Kırıkkale Üniversitesi Fen Bilimleri Enstitüsü Biyoloji Anabilim Dalı, Yüksek Lisans Tezi, $198 \mathrm{~s}$.

Tunaz H., Işıkber A. A., Er M. K., Mart C., Uygun, N. ve Satar S. (2010). Coccinellid parazitoiti, Dinocampus (Perilitus) coccinellae (Schrank) (Hymenoptera: Braconidae) tarafindan parazitlenen Coccinella septempunctata L. erginlerinin Adana, Osmaniye ve Mersin illerinde dağılımı. Türkiye Biyolojik Mücadele Dergisi, 1(2):139-150.

TÜİK (2019). Türkiye İstatistik Kurumu Web Sayfası. www.tuik.gov.tr (Erişim Tarihi: 04.09.2020)

Uygun, N. (1981). Türkiye Coccinellidae (Coleoptera) Faunası Üzerinde Taksonomik Araştırmalar. Ç.Ü. Ziraat Fakültesi Yayınları, Adana Bilimsel Araştırma ve İnceleme Tezleri, 48: $110 \mathrm{~s}$.

Vilaivan V., Amornsak W. and Gordh G. (2016). Development, reproduction and longevity of Aprostocetus sp. (Hymenoptera: Eulophidae), an egg parasitoid of the Brown planthopper, Nilaparvata lugens (Stal) (Hemiptera: Delphacidae). 


\section{Ricania japonica (Hemiptera: Ricaniidae)'nın Biyolojik Mücadelesinde Kullanılabilecek Potansiyel Doğal Düşmanların Belirlenmesi}

Agriculture and Natural Resources, 50(4): 291-294.

White T. J., Bruns T, Lee S. and Taylor J. (1990).

Amplification and Direct Sequencing of Fungal Ribosomal RNA Genes for Phylogenetics. In: PCR Protocols: A Guide to Methods and Applications, eds. Innis, M. A., D. H. Gelfand, J. J. Sninsky, and T. J. White. Academic Press, Inc., New York, Pp. 315-322.

Yefremova Z. A., Civelek H. S., Boyadzhıev P. S., Dursun O. and Eskin A. (2010). Contributions to the Turkish Eulophidae (Hymenoptera, Chalcidoidea) with new records. Türkiye Entomoloji Dergisi, 34(4): 447-463.

Zimmermann G. (2007). Review on safety of the entomopathogenic fungi Beauveria bassiana and Beauveria brongniartii. Biocontrol Science and Technology, 17(5/6): 553-596. 
Ricania japonica (Hemiptera: Ricaniidae)'nın Biyolojik Mücadelesinde Kullanılabilecek Potansiyel Doğal Düşmanların Belirlenmesi 